Susan F. Martin, Sanjula Weerasinghe, Abbie Taylor (eds)

\section{Humanitarian Crises and Migration: Causes, Consequences and Responses}

London - New York: Routledge, 2014, 376 str.

DOI: 10.11567/met.31.3.5

Knjiga Humanitarian Crises and Migration: Causes, Consequences and Responses sadržava sedamnaest poglavlja koja se bave vrlo aktualnom temom izbjeglica, prisilnih migranata koji bježe iz određenog područja zahvaćenoga krizom. Pod krizom se ne podrazumijevaju samo ratni sukobi nego i druge vrste pojava koje mogu uzrokovati prisilne migracije ljudi, primjerice poplave, potresi, epidemije itd. Riječ je o zborniku radova iz pera nekih od najvećih svjetskih stručnjaka na tom području, a osobita pozornost posvećena je humanitarnim aspektima migracija.

Radovi u zborniku podijeljeni su $\mathrm{u}$ četiri dijela. $\mathrm{U}$ prvome »Introduction and a Theoretical Perspective" oni su koji se tiču teorijske razrade pojma krizne migracije, drugi »Case Studies of Humanitarian Crises: Movements, Protection Implications and Responses« donosi recentnije primjere obrađene metodom studije slučaja, treći dio »At Risk Populations" analizira položaj raznih vrsta ugroženih populacija, dok se u radu u četvrtom dijelu »Governance« predlažu mjere za rješenje pitanja kriznih migracija na globalnoj razini.

Krizna migracija tek je nedavno uveden krovni pojam i označuje razne vrste premještanja skupina stanovništva pod prisilom koja im onemogućuje da nastave živjeti na području na kojem su prije živjele. Često su uzrokovane nečim što se obično naziva humanitarna kriza. Autori ovog zbornika predložili su radnu definiciju tog pojma: riječ je o bilo kakvoj situaciji u kojoj za određenu skupinu stanovništva postoji raširena opasnost za život, fizičku sigurnost, zdravlje ili osnovnu egzistenciju, pri čemu pojedinci i zajednice koji žive na dotičnom području nisu u stanju sami se nositi s tom ugrozom (str. 5). Autori zbornika zalažu se za razradu modela pomoću kojih bi se na globalnoj razini mogli rješavati problemi nastali takvim vrstama prisilnog premještanja stanovništva.

U prvom dijelu knjige razrađuje se i problematizira razlika između raznih vrsta migranata. Dovodi se u pitanje inače raširena distinkcija između "proaktivnih" ili »reaktivnih" te dobrovoljnih i prisilnih migranata. Zaključuje se da potpuno »dobrovoljni« migranti ne postoje. Naznačuje se da će se više pozornosti dati tipovima migracija nego uzrocima, ali istodobno ne podcjenjujući važnost uzroka. Naime poznavanje tipova prisilnih migracija važnije je sa stajališta organiziranja pomoći pogođenim populacijama. Razlikuju se tri tipa prisilnih migracija: 1. premještanje ljudi iz krizom zahvaćenih područja zbog ugroženosti života ili zdravlja (bilo putem bijega, kaotičnog ili organiziranog, ili evakuacije), 2. preventivni pokret stanovništva (do kojeg dolazi kad ljudi na nekom području osjete opasnost koja se nadvila nad njih te žele pobjeći prije nego što dođe do najgorega) i 3. relokacija zarobljenog stanovništva (ovdje je riječ o ljudima koji bi mogli i htjeli bježati s određenog područja, ali 
to iz nekog razloga ne mogu učiniti, te se onda uključuju razne međunarodne organizacije koje to organiziraju).

Autorima je jasno da mehanizmi pomoći prisilnim migrantima još nisu sasvim razrađeni na globalnim razinama. Ima mnogo nedosljednosti i ad hoc rješenja, nisu uvijek jasne kompetencije pojedinih međunarodnih organizacija i država, a također se jasno ne pravi razlika između raznih tipova prisilnih migranata, što bi olakšalo bavljenje pojedinim slučajevima.

Jane McAdam smatra da se izbjeglicama zbog prirodnih nedaća dosada posvećivala manja pozornost nego prognanicima iz ratnih područja. Jedan od izričito postavljenih ciljeva ove knjige jest $\mathrm{i}$ da ispravi tu nepravdu time što će se stvoriti sveobuhvatan pojam kriznog migranta koji će obuhvatiti obje kategorije, što će olakšati osmišljavanje globalne politike upravljanja migrantskim krizama.

Isto tako, važno je razviti mehanizme preventivnog djelovanja. Većina akcija pomoći migrantima dosada se provodila kad bi već došlo do krizne migracije. Jane McAdam smatra da u nekim situacijama treba znati predvidjeti krizu (dakako, za to moraju postojati jasni znakovi) i odmah djelovati, a ne čekati da krizna migracija i s njom povezana humanitarna kriza počnu.

Drugi dio knjige obuhvaća deset studija slučaja kriznih migracija i humanitarnih kriza koje su se dogodile posljednjih godina. Riječ je o različitim vrstama migracija, ali se prednost daje onima zbog prirodnih nepogoda, jer se tom tipu migracija dosad posvećivala manja pozornost. Analiziraju se razvoj događaja u pojedinim slučajevima te način na koji su se dr- žavne i međunarodne organizacije suočile s krizama. Studije se bave poplavama u Pakistanu i Kolumbiji, humanitarnom krizom u Haitiju (nastalom kao rezultat potresa iz 2009.), problemima premještanja stanovništva zbog epidemija, fenomenom bijega stanovništva zbog ratova kriminalnih kartela u Meksiku i Srednjoj Americi, pitanjem sjevernokorejskih prebjega u Kinu i mianmarskih migranata u Tajlandu, migracijama u Somaliji (uzrokovanim kombinacijom političkih sukoba i ekoloških problema), pitanjem zaštite prava migranata, migracijama zbog klimatskih promjena, preseljenjima čitavih zajednica blizu Arktika i u Južnom Pacifiku te općenito problemom preseljavanja u 21. stoljeću.

Jedna studija bavi se slučajem Somalije iz 2011., jer tu je riječ o primjeru migracije koja ima složene uzroke. $S$ jedne je strane to suša koja je uzrokovala glad, a s druge obnova oružanih sukoba $u$ toj zemlji kontinuirano od 1991. razdiranoj građanskim ratom. Slučaj Somalije pridonio je širenju svijesti o tome da se pri rješavanju kriza te vrste ne treba osloniti samo na »klasične «, bilo nacionalne (tj. državne), bilo internacionalne strukture, nego da se treba koristiti i »tradicionalnim « strukturama lokalnih društava tamo gdje su one nazočne, kao što su na primjer mreže religiozne (islamske) ili klanske potpore.

U trećem dijelu knjige, koji analizira probleme raznih vrsta populacija izloženih riziku kriznih migracija, osobita pozornost posvećena je »nedržavljanima« (Khalid Koser), tj. strancima koji se nađu u nekoj zemlji u kojoj izbije kriza, te su »zarobljeni« $u$ takvoj situaciji i ne mogu se vratiti u zemlju iz koje dolaze. Ljudi koji dospiju 
u takvu situaciju često su izloženi specifičnim pogibeljima koje proizlaze iz toga što kao stranci nerijetko ne mogu računati na pomoć koju države daju svojim državljanima, drugim riječima, javlja se opasnost od diskriminacije. Kao primjeri navode se situacije tijekom rata između Izraela i Hezbolaha u Libanonu 2006. (kada su u zemlji ostali zarobljeni brojni stranci), ksenofobnog nasilja u Južnoafričkoj Republici 2008. (građani drugih afričkih zemalja), rata u Libiji 2011. (strani radnici i imigranti iz drugih dijelova Afrike) i neke druge. Preporučuje se provođenje daljnjih istraživanja specifičnih problema i teškoća s kojima se susreću krizni migranti koji nisu državljani zemlje u kojoj izbije kriza. Khalid Koser između ostaloga smatra da treba potaknuti države na donošenje zakona kojima bi specifično štitile prava i interese nedržavljana na svom području.

Jedno poglavlje posvećeno je fenomenu bijega stanovništva pogođenog nasiljem ili prirodnim nepogodama $\mathrm{u}$ velike gradove (Patricia Weiss Fagen). Kada katastrofe izazvane devastacijom okoliša ili ratovima pogode seoske sredine, često se događa da stanovništvo masovno bježi u gradove. Sredine koje ovise o neposrednoj proizvodnji i konzumaciji vlastite hrane (tj. životu od poljoprivrede) ranjivije su na negativne posljedice globalizacije nego veliki gradovi, u kojima postoji (barem teoretski) veća mogućnost da se nađe posao, makar za puko preživljavanje. To je zato što su gradovi financijska i poslovna središta i što su globalno bolje međusobno povezani. Bijeg stanovništva sa sela u gradove stvara siromašna predgrađa, favele i slamove, u kojima prevlada- vaju nabrzinu sklepane kuće, loša infrastruktura i endemski kriminalitet, a većina stanovnika osuđena je na život $\mathrm{u}$ siromaštvu i besperspektivnosti do daljnjega. Dok se prije smatralo da su gradovi loša mjesta za život za prebjege iz poljoprivredne sredine, $u$ posljednje vrijeme stručnjaci s tog područja sve su uvjereniji da su gradovi mjesta u kojima treba pokušati riješiti problem kroničnog siromaštva, tj. da treba učiniti sve da se stanovništvo iz favela integrira $\mathrm{u}$ život $\mathrm{u}$ velikim gradovima i da ima koristi od svih mogućnosti koje oni pružaju (umjesto da se prave planovi o povratku u seoske sredine).

U zaključku zbornika Alexander Betts zalaže se za globalno upravljanje migracijskim krizama, uzimajući kao polazišnu točku krovni termin koji obuhvaća premještanje stanovništva (uključujući i ono koje se nalazi izvan postojećih zaštitnih mehanizama), spašavanje stanovništva zarobljenog na nekom području, miješanu migraciju (onu do koje dolazi kombinacijom raznih čimbenika) te preventivna kretanja stanovništva (do kojih dolazi kad ljudi s nekog područja shvate da će u doglednoj budućnosti doći u opasnost za život ili zdravlje). Nakon Drugoga svjetskog rata u svijetu su nastale brojne organizacije koje se bave pitanjem izbjeglica, ali se njihove ingerencije često preklapaju, a preklapaju se i s ingerencijama pojedinih vlada, što dovodi do »kompleksnosti režima«. U tu kompleksnost režima zaštite kriznih migranata treba uvesti red da bi se lakše organiziralo olakšavanje ili rješavanje migrantskih kriza na međunarodnoj razini. Globalno upravljanje krizom, inače prilično kontroverzan pojam, ovdje se de- 
finira kao »sveukupnost djelovanja usmjerenih prema organiziranju kolektivne akcije uz sudjelovanje država i transnacionalnih tijela« (str. 351). Pritom je ključno međudjelovanje režima upravljanja migracijom i režima rješavanja humanitarnih pitanja. Zaključak je da za globalno upravljanje kriznim migracijama nije potrebno izmišljati toplu vodu, to jest neke nove norme, nego dosljedno provoditi postojeće, a sve to uz bolju koordinaciju nacionalnih i internacionalnih organizacija koje se bave pitanjima migracija i humanitarnih kriza.

Vrijednost je ovog zbornika u tome što nisu samo teorijski razrađeni modeli raznih vrsta prisilnih migracija, nego je naveden čitav niz pojedinačnih slučajeva, s mnoštvom podataka s terena, a daju se i preporuke za rješavanje problema nastalih prisilnim migracijama diljem svijeta. Prisilne migracije više se razlikuju prema načinima na koje se odvijaju i prema konkretnim problemima s kojima se susreću oni koji u njima sudjeluju nego po uzrocima (bili to problemi okoliša, epidemije, ratovi, prirodne nepogode itd.). Cilj je potaknuti stvaranje globalnoga integriranog sustava upravljanja migracijskim krizama koji bi prevladao dosadašnja polovična, ad hoc rješavanja problema i preklapanja nadležnosti između raznih nacionalnih i internacionalnih tijela.

\section{Boris Nikšić}

Institut za migracije i narodnosti, Zagreb 